\title{
O TANGÍVEL E O,CORPÓREO DAS BIBLIOTECAS PÚBLICAS BRASILEIRAS: do ideal ao real
}

\section{THE TANGIBLE AND THE CORPOREAL OF BRAZILIAN PUBLIC LIBRARIES: from the ideal to the real}

\author{
Bruna Daniele de Oliveira Silva \\ Deise Maria Antonio Sabbag²
}

\begin{abstract}
RESUMO
As Bibliotecas Públicas (BPs) são instituições com um enorme potencial de transformação social. É nessas instituições que 0 indivíduo pode desenvolver capacidades e habilidades para manipular e expandir o conhecimento por meio do acesso à informação, atividade fundamental para a formação do cidadão. No entanto, as BPs do Brasil possuem diferenças enormes devido à própria capilaridade geográfica brasileira, a gritante diferença trazida pela era digital, bem como a falta de políticas públicas efetivas, aumentam o hiato entre essas instituições com a realidade da comunidade em seu entorno. Esses distanciamentos colocaram as BPs como lugares esquecidos pela sociedade e negligenciados pelo poder público. Nesta perspectiva, o presente artigo teve como objetivo diagnosticar a situação atual das BPs brasileiras. A pesquisa teve caráter descritivo com abordagem quali-quantitativa a partir de aplicação de questionário em BPs. Os dados indicam que mais da metade (54\%) dos responsáveis pela biblioteca não tem formação na área de Biblioteconomia, apesar de $92 \%$ dos respondentes terem formação superior. Quase metade (44\%) das BPs contam com apenas um funcionário, impossibilitando o desenvolvimento de diversas atividades na unidade. Cerca de $70 \%$ das BPs funcionam apenas em horário comercial e $64 \%$ tiveram seu espaço adaptado para ser uma biblioteca. A análise apresentou dados, por vezes, aflitivos. É certo que essas instituições têm sido negligenciadas há tempos nas diferentes hierarquias administrativas em que estão inseridas. Para mudar esse panorama é preciso a implementação de ações em âmbito local e nacional, de forma a trazer as bibliotecas públicas brasileiras definitivamente ao século XXI.
\end{abstract}

Palavras-chave: Biblioteca Pública. SNBP. Acesso à informação. Recursos da Biblioteca. Infraestrutura da Biblioteca.

\begin{abstract}
Public libraries (BPs) are institutions with enormous potential for social transformation. It is in these institutions that the individual can develop skills and abilities to manipulate and expand knowledge through access to information, a fundamental activity for the formation of the citizen. However, the Brazilian BPs have enormous differences due to the Brazilian geographical capillarity itself, the stark difference brought about by the digital age, as well as the lack of effective public policies, increase the gap between these institutions and the reality of the community around them. These distances have placed BPs as places forgotten by society and neglected by public power. In this perspective, this article aimed to diagnose the current situation of Brazilian BPs. The research was descriptive with a qualitative-quantitative approach based on the application of a questionnaire in BPs. The data indicate that more than half $(54 \%)$ of those in charge of the library are not trained in Librarianship, although $92 \%$ of the respondents have higher education. Almost half (44\%) of the BPs have only one employee, making it impossible to develop several activities in the unit. About $70 \%$ of the BPs work only during business hours and $64 \%$ have their space adapted to be a library. The analysis presented data, sometimes distressing. It is true that these institutions have long been neglected in the different administrative hierarchies in which they are inserted. To change this scenario, it is necessary to implement actions at the local and national levels, in order to bring Brazilian public libraries to the 21 st century.

Keywords: Public Library. SNBP. Access to information. Library Features. Library Infrastructure.
\end{abstract}

Artigo submetido em 12/08/2019 e aceito em 29/11/2019

1 Bacharel em Biblioteconomia e Ciência da Informação pela Universidade de São Paulo. Foi bolsista CNPq de Iniciação Científica entre 2016-2017. Mestranda em Ciência de Informação pela Universidade Estadual Paulista - UNESP com bolsa da CAPES. E-mail: bruna.daniele.silva@alumni.usp.br.

2 Doutora em Ciência da Informação pela Universidade Estadual Paulista Júlio de Mesquita Filho, Brasil. Professora Doutor da Universidade de São Paulo, Brasil. E-mail: deise.sabbag@unesp.br. 


\section{INTRODUÇÃO}

Apesar dos mitos que circulavam em torno da ascensão da internet, entre eles 0 de que a biblioteca física ficaria obsoleta, tanto a biblioteca quanto o profissional da informação continuam sendo necessários, senão mais necessários, devido à explosão informacional, a internet das coisas, o big data, a ciência dos dados etc. A biblioteca pública mantém-se firme, apesar dos descasos do poder público, pelo papel social que ela exerce, não apenas como um local que empresta livros, mas como ferramenta de integração social que atua no auxílio da aprendizagem formal e informal.

Mesmo tendo modificado seus objetivos ao longo do tempo, podendo ser científico ou religioso, as bibliotecas sempre teceram um papel indispensável na preservação e transmissão do conhecimento, possibilitando o progresso e criação de novos conhecimentos. É certo dizer, também, que 0 acesso a todo esse conhecimento sempre foi, e ainda hoje 0 é limitado em vários âmbitos, como o socioeconômico, geográfico e até mesmo pelo grau de alfabetização do usuário, que pode ser analfabeto ou analfabeto funcional.

Dominar a informação e, principalmente, suas fontes de produção, significa ter poder e influência na sociedade, frente a essa realidade compreende-se o porquê da manipulação e limitação do acesso ao conhecimento. A biblioteca de Alexandria contava com cerca de 700.000 rolos de papiro, por seu caráter inovador em que não impunha restrições de conteúdo ou de crenças, a biblioteca foi destruída em sucessivas guerras travadas por religiosos que desconheciam a importância de seu conteúdo (MEY, 2004), demonstrando como é essencial que o conhecimento não seja monopolizado, mas discutido amplamente a fim de que cada cidadão tenha capacidade de formar a própria opinião.

As Bibliotecas Públicas (BPs) são instituições com um enorme potencial de transformação social. É nessas instituições que 0 indivíduo pode desenvolver capacidades e habilidades que os farão um cidadão. Frente a essa realidade, o presente artigo buscou diagnosticar a situação atual das BPs brasileiras, desde 0 acesso a dados cadastrais no sistema nacional até dados sobre sua estrutura, funcionamento, produtos e serviços, disponibilidade de profissionais, entre outros.

A metodologia partiu de uma abordagem descritiva de caráter quali-quantitativo, foi aplicado questionário nas BPs cadastrados no Sistema Nacional de Bibliotecas Públicas (SNBP) para coleta de dados. 


\title{
2 BIBLIOTECA PÚBLICA: UM OLHAR IDEALIZADO
}

\author{
A Biblioteca Pública (BP) pode ser definida como:
}

\begin{abstract}
uma organização fundada, sustentada e financiada pela comunidade, quer através do governo local, regional ou nacional quer através de outras formas de organização comunitária. Proporciona o acesso ao conhecimento, à informação e a obras criativas através de um leque variado de recursos e serviços e encontra-se à disposição de todos os membros da comunidade, sem distinção de raça, nacionalidade, idade, sexo, religião, língua, deficiência, condição económica e laborais e qualificações académicas. (GILL, 2001, p. 19)
\end{abstract}

A partir dessa definição percebe-se os caracteres universal e democrático da BP, pois todos seus recursos devem estar alinhados de forma a atender todos os cidadãos, garantindo o direito primordial de acesso à informação. Ela é, portanto, "o centro local de informação, tornando prontamente acessíveis aos seus utilizadores o conhecimento e a informação de todos os gêneros" (MANIFESTO, 1994, online). Seu objetivo principal é "preservar e difundir o conhecimento, [...] dentre todos os tipos de bibliotecas é a única que possui características de uma instituição social” (SUAIDEN, 1995, p. 20). Ela é "a instituição que tem as melhores condições de formar um público leitor" (SUAIDEN, 1995, p. 42), desde que sejam desenvolvidas ações para tal. Seus objetivos básicos são "providenciar recursos e serviços através de meios variados para dar resposta às necessidades de indivíduos e grupos nas áreas da educação, informação e desenvolvimento pessoal, incluindo a recreação e o lazer" (GIL, 2001, p. 20).

A BP contribui para o desenvolvimento pessoal do indivíduo fornecendo materiais que estimulem a criatividade e desenvolvam novos interesses, além de fornecer informações relevantes sobre problemas comuns na comunidade, tais como: prevenção de doenças, desenvolvimento de competências básicas e materiais para analfabetos. As BPs também devem estimular hábitos de leituras, em particular com crianças e jovens, por meio da disponibilização de materiais adequados àqueles que estão sendo alfabetizados; a frequência deles na biblioteca pode estimular os pais a utilizarem esses espaços.

A BP deve ser ainda um centro de desenvolvimento cultural e artístico, proporcionando materiais e acessos que atendam aos mais diversos interesses, se necessário, deve criar parcerias com outros espaços que fomentem o desenvolvimento de projetos culturais. A BP exerce, portanto, um papel social no auxílio à educação e na disponibilização de atividades culturais, atua como ponto de encontro da comunidade a que serve, garante acesso à informação e serviços a todos, inclusive desenvolvendo ações para agregar grupos minoritários, garante que as necessidades informacionais sejam atendidas e avaliadas constantemente, de forma a garantir 0 direito à diversidade. 
Idealmente, as BPs devem ser planejadas desde o espaço físico, visando à acessibilidade para o público com necessidades especiais de locomoção e, também, para permitir que se desenvolvam atividades e serviços. Outro ponto no âmbito do ideal são os recursos, segundo as diretrizes da IFLA/ UNESCO:

Para cumprir as suas funções de forma satisfatória, a biblioteca pública deve possuir recursos apropriados em permanência, e não somente quando da sua criação, de forma a possibilitar a sustentação e desenvolvimento de serviços que vão ao encontro das necessidades da comunidade local (GIL, 2001, p. 31).

No Brasil, esses aspectos ficam somente no âmbito da idealização, do imaginário e do quimérico, tendo esse olhar longitudinal a pesquisa foi realizada buscando elementos factuais e tangíveis sobre a realidade das BPs do país.

\section{BIBLIOTECA PÚBLICA BRASILEIRA, LEITURA E ACESSO A INFORMAÇÃO: A REALIDADE}

A biblioteca pública foi criada na Inglaterra no contexto da Revolução Industrial tendo como objetivos a educação e a moralização da classe trabalhadora (FUNDAÇÃO, 2010). Sua missão foi se modificando ao longo das décadas de forma a se adequar às mudanças nas necessidades informacionais, os documentos norteadores dessas mudanças foram os Manifestos da IFLA/ UNESCO sobre Bibliotecas Públicas (FUNDAÇÃO, 2010). 0 primeiro Manifesto foi publicado em 1949 e colocava a biblioteca como centro de educação popular; o segundo Manifesto teve como objetivo ressaltar o caráter social da biblioteca, dessa forma, elencou "como suas funções educação, cultura, lazer e informação" (FUNDAÇÃO, 2010, p. 20); o terceiro Manifesto, o mais recente, foi publicado em 1994 e tem como foco a democratização do acesso às tecnologias da informação (FUNDAÇÃO, 2010).

No Brasil, a primeira biblioteca pública foi inaugurada em 1811 na cidade de Salvador - BA, já nesta época era destacada sua função de apoio à educação (FUNDAÇÃo, 2010). 0 desenvolvimento dessas instituições no Brasil ocorreu no contexto em que a maioria de sua população era analfabeta, criando assim, o mito em que esses lugares servem apenas a uma elite intelectual (SUAIDEN, 2000). 0 desenvolvimento de programas de alfabetização fez com que as bibliotecas públicas fossem frequentadas majoritariamente por estudantes, ocorrendo o fenômeno da "escolarização da biblioteca pública” (SUAIDEN, 2000, p. 55); tal fenômeno persiste até hoje. 
Com a evolução do acesso a internet o panorama ficou ainda mais excludente, pois o público, antes composto de escolares, migrou para o ambiente digital, ratificando a prática da pesquisa em servidores de busca (MILANESI, 2013). Nesse contexto, faz-se necessário desconstruir o estereótipo da biblioteca como lugar escuro, empoeirado e silencioso. Sendo ela um local que auxilia na produção de conhecimento - e este conhecimento nasce a partir do debate e da integração de outros conhecimentos - não pode ser segregadora. Assim, no panorama atual, pensar novos incentivos para que a população passe a frequentar a BP é de extrema importância devido ao potencial que ela tem de auxiliar no processo democrático, principalmente nos dias atuais em que a transparência do mal parece naturalizada pelos poderes que a olhos vistos exercem o fascismo.

0 acesso à informação promove o processo democrático, alavancado pelo direito à leitura consciente e interpretadora que leva a transformação da realidade. A biblioteca como ambiência interpretativa e incentivadora da leitura resgata sua relevância social. Comprometer-se com a leitura significa preparar cidadãos para exercerem seus direitos, influenciando toda a sociedade e contribuindo para garantir a democracia. Pessoas capacitadas para encontrar e interpretar informações tem condições para formar opiniões próprias, baseadas em raciocínio e não em indução. Na era digital, em que a internet tem potencial de ser a ferramenta para o acesso democrático à informação, a realidade é subvertida a intensa propagação das fake news, isso ocorre devido à falta de preparo das pessoas para receberem essas informações e a incapacidade de interpretar textos e imagens adulterados, por mais absurdas que sejam.

Capacitar pessoas para pesquisar, selecionar, interpretar e utilizar a informação é chamada Literacia Informacional. Esse conceito tem sido frequentemente relacionado com a Literacia Informática, que trata da capacidade dos indivíduos de utilizarem as tecnologias da informação. Ambos os conceitos estão intimamente relacionados com a leitura e com o fomento da alfabetização. No âmbito da biblioteca pública, o desenvolvimento dessas competências nos usuários pode levar ao melhor aproveitamento dos recursos e serviços da instituição e, consequentemente, à melhora dos mesmos. No âmbito do indivíduo, tais competências "têm profundas implicações individuais e sociais, para além de econômicas" (CALIXTO, 2003, p. 3). "Níveis de literacia elevados são hoje associados à empregabilidade e à cidadania" (OECD, 2000 apud CALIXTO, 2003, p.3), dessa forma, tornar o cidadão apto a lidar com a informação vai muito além de exercício técnico, é um exercício democrático.

Infelizmente, 0 aumento no número de pessoas lendo e escrevendo na rede não as tornou mais aptas a buscar e/ou selecionar informação com qualidade. A ascensão das fake news é a prova de que 
as pessoas não desenvolvem a capacidade de julgar o teor da notícia que compartilham e, ainda assim, as defende com convicção. 0 Relatório de Notícias Digitais do Instituto Reuters (2018) mostra que no Brasil, $66 \%$ da amostra utiliza mídias sociais como fonte de notícias, $52 \%$ através da rede social Facebook (é o país com a maior porcentagem) e 48\% utiliza o aplicativo WhatsApp.

0 fato é que, pelo menos no Brasil, o meio digital ainda é campo pouco conhecido pela população, isto é, as pessoas consomem seus serviços e suas ferramentas, mas não tem a mínima noção de como são desenvolvidos. 0 acesso a internet é visto por muitos apenas como uma ferramenta para acessar aplicativos populares como WhatsApp e Facebook, como as funções são intuitivas, não exigem muito conhecimento por parte dos usuários. Para esses mesmos usuários, muitas vezes são desconhecidas funções básicas como a edição de uma imagem, de vídeo, entre outros, essa pode ser a origem da rápida propagação das notícias falsas, por desconhecerem processos, os usuários acreditam que manipular informações seja tarefa difícil ou inviável. Obviamente, parte dos propagadores de desinformação age conscientemente e tem como objetivo a manipulação de pessoas, no entanto, boa parte de sua difusão é feita por pessoas que estão iniciando o uso de dispositivos digitais ou que tem limite de acesso à internet, isto é, usam a internet através de pacotes de dados. Assim, fica evidente a necessidade de capacitar usuários através dos letramentos (ou literacias) informacional e digital. Neste sentido, a biblioteca pública se apresenta como um local viável para essa capacitação, no entanto, primeiro é necessário reformular a imagem dessas instituições para atrair o público.

No Brasil, cerca de 56\% da população são leitores, - para o propósito da pesquisa do Instituto, define-se leitor como "aquele que leu, inteiro ou em partes, pelo menos 1 livro nos últimos 3 meses" (INSTITUTO PRÓ-LIVR0, 2016, p. 21). Esse dado aliado a problemas como 0 analfabetismo funcional e exclusão social, evidencia a necessidade de desenvolver novas ferramentas para engajar a leitura, pensando em formas de se comunicar com os leitores em potencial. A BP se apresenta como a instituição com maior potencial de formar leitores.

\section{METODOLOGIA}

A presente pesquisa tem caráter descritivo com abordagem quali-quatitativa. Como ferramenta de coleta de dados foi aplicado questionário utilizando a ferramenta Formulários do Google Drive. Como método para análise dos dados foi utilizado a Análise de Conteúdo a partir de estudo estruturado do conteúdo. 
Para o recorte de público do questionário utilizamos dados cadastrais extraídos do Sistema Nacional de Bibliotecas Públicas (SNBP). Às bibliotecas públicas que apresentaram endereço de e-mail foi enviado o questionário, as restantes, por questões de logística (facilidade na coleta e armazenamento dos dados) e financeira (custo zero no envio de e-mail em contraponto às chamadas telefônicas entre estados, que são de alto custo e se apresentam como a única opção além do e-mail) não foram consideradas para a coleta de dados.

No momento da pesquisa eram 6.057 bibliotecas públicas cadastradas no Sistema Nacional de Bibliotecas Públicas, no entanto, muitas delas não apresentavam endereço de e-mail, além disso, os dados foram atualizados em 2015, devido a isso, muitos e-mails estavam desatualizados. Após elaborar uma planilha no aplicativo Excel com os dados das bibliotecas que possuíam endereço de e-mail, chegou-se a uma amostra de 2.742 e-mails, representando 23 estados das cinco regiões do país, pois alguns estados e o Distrito Federal não apresentaram nenhum endereço de e-mail.

Após o envio dos e-mails, pelo menos um quarto deles retornou a caixa de entrada do emissor. Com dois meses de questionário ativo ainda havia um bom número de estados sem representação nas respostas, para contornar essa situação foram feitas buscas por e-mails atualizados em sites de prefeituras, blogs e páginas no facebook. Essa ação também se aplicou no sentido de buscar representação dos estados que não apresentaram nenhum e-mail na planilha.

0 Sistema Nacional de Bibliotecas Públicas (SNBP) é um órgão instituído através de decreto presidencial em 1992. O decreto o colocou como órgão subordinado à Fundação Biblioteca Nacional (FBN), atualmente ele está vinculado ao Ministério da Cultura (MinC). Ele atua em nível federal e é o elo que une e articula os 27 Sistemas Estaduais de Bibliotecas Públicas (SEBPs), de forma a fortalecer as políticas e as ações de promoção do livro e da leitura. Em conjunto com órgãos de diferentes esferas administrativas, o SNBP desenvolve diversos programas nas áreas de leitura, literatura e bibliotecas, além de levantar a bandeira do Plano Nacional do Livro e Leitura (PNLL), de forma a engajar os sistemas a criarem planos em suas próprias esferas de atuação (SNBP, 2018).

\section{RESULTADOS}

Após análise dos questionários o conteúdo foi dividido em 5 categorias e 17 inferências, conforme quadro a seguir: 
Quadro 1 - Categorias e Inferências

\begin{tabular}{|c|c|}
\hline CATEGORIAS & INFERÊNCIAS \\
\hline \multirow[b]{3}{*}{$\begin{array}{l}1^{\text {a }} \text { Categoria: Delineamento } \\
\text { da amostra }\end{array}$} & Bibliotecas públicas no Brasil \\
\hline & Bibliotecas com endereço de e-mail \\
\hline & Índices de respostas obtidas \\
\hline \multirow[b]{2}{*}{$\begin{array}{c}\text { 2a Categoria: }^{\text {a }} \\
\text { Caracterização das } \\
\text { Bibliotecas }\end{array}$} & Tipos de bibliotecas respondentes \\
\hline & Relação do horário de funcionamento das bibliotecas respondentes \\
\hline \multirow[b]{4}{*}{$\begin{array}{l}3^{\text {a }} \text { Categoria: } \\
\text { Caracterização dos } \\
\text { respondentes }\end{array}$} & Relação da Faixa Etária dos respondentes \\
\hline & Gênero dos respondentes \\
\hline & Tempo de atuação dos respondentes nas unidades \\
\hline & $\begin{array}{l}\text { Relação de nível e área de formação dos funcionários das bibliotecas } \\
\text { respondentes }\end{array}$ \\
\hline \multirow{5}{*}{$\begin{array}{l}4^{\text {a }} \text { Categoria: Infraestrutura } \\
\text { e serviços das Bibliotecas }\end{array}$} & Sobre os espaços que abrigam as Bibliotecas \\
\hline & Tipos de ambientes/setores pertencentes às Bibliotecas \\
\hline & Recursos materiais das bibliotecas \\
\hline & Tipos de materiais pertencentes ao acervo das bibliotecas \\
\hline & Relação de serviços oferecidos pelas bibliotecas \\
\hline \multirow[b]{3}{*}{$\begin{array}{l}5^{\text {a }} \text { Categoria: Recursos } \\
\text { Humanos }\end{array}$} & Número de funcionários que atuam nas bibliotecas \\
\hline & Formação do quadro de funcionários da biblioteca \\
\hline & Qualificação dos funcionários \\
\hline
\end{tabular}

Fonte: Autoria própria

Na primeira Categoria, 'Delineamento da Amostra', foram comparados o total de bibliotecas, 0 total de bibliotecas com endereços de e-mail e o total de respostas (todos os levantamentos considerando região ou estado).

A primeira Inferência dentro da Categoria 1 é 'Bibliotecas Públicas no Brasil'. A partir dessa Inferência foram somados os totais de bibliotecas apresentadas nas planilhas fornecidas no site do SNBP. 
Gráfico 1: Números totais de bibliotecas públicas por região

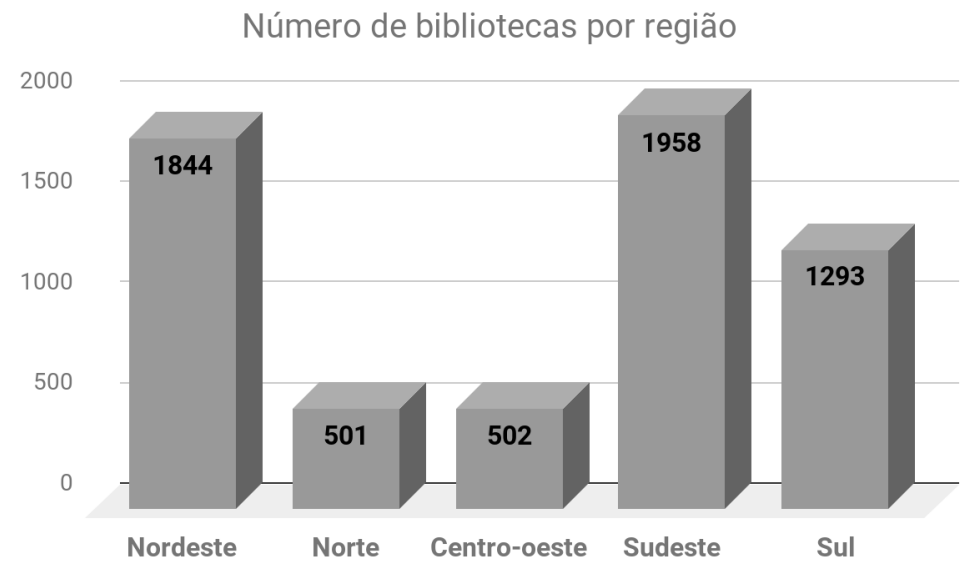

Fonte: autoria própria

Gráfico 2: Porcentagem de bibliotecas públicas por região

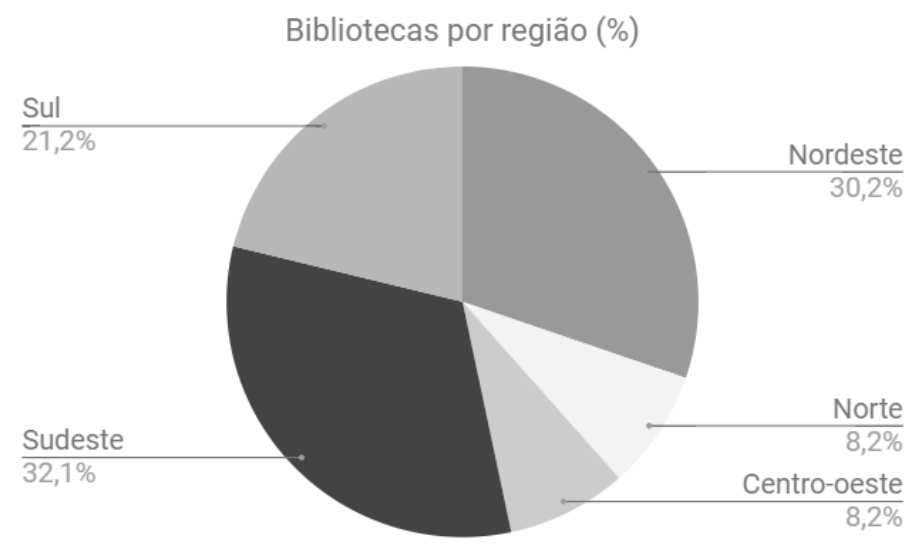

Fonte: autoria própria

Um dado interessante que pode ser extraído desses totais é que apesar de Nordeste e Sudeste terem uma porcentagem de BPs próxima, quando considerado o número de estados que constituem a região Nordeste (9) e o Sudeste (4) a média de bibliotecas por estado fica bem mais baixa no Nordeste, ficando próxima de 204 bibliotecas por estado, já no sudeste essa média dobraria. No entanto, quando considerada a população de ambas as regiões, Nordeste com 56.000 .000 (IBGE, 2016) de habitantes e Sudeste com 86.000.000 (IBGE, 2016) de habitantes, a região Nordeste tem mais bibliotecas por número de habitantes.

A Inferência seguinte é Bibliotecas com endereço de e-mail, que visou avaliar o total de BPs que possuem e-mails registrados no SNBP. Quando considerada apenas as BPs com endereços de e-mail 0 número reduz drasticamente, ficando abaixo dos $50 \%$ do total de BPs do país, como mostra 0 gráfico 3 : 
Gráfico 3: Biblioteca com endereço de e-mail (\%)

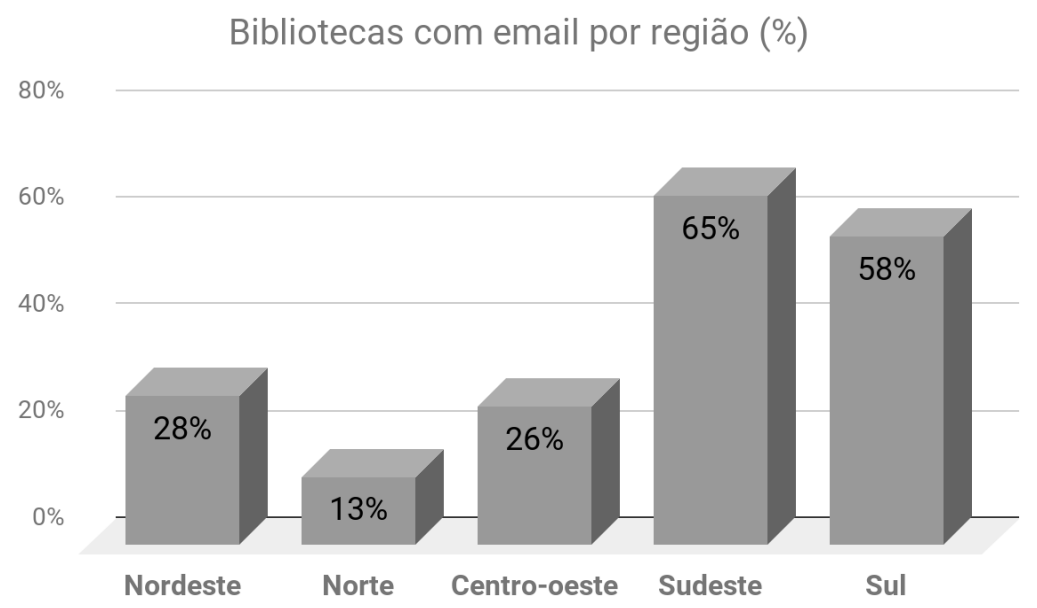

Fonte: autoria própria

Os dados desses gráficos mostram o total de BPs que possuem endereço de e-mail em relação ao total de BPs de cada região. Nesse caso, as regiões Sul e Sudeste contam com maior número de bibliotecas com endereço de e-mail, esse dado pode ser explicado pelo fato de serem as regiões, economicamente, mais desenvolvidas do país, característica que pode influenciar na aquisição e uso da tecnologia.

Analisando os dados, percebe-se que alguns estados se destacam na região a qual pertencem pelo número de BPs com endereço de e-mail que possuem, para mais ou para menos:

Gráfico 5: Número de bibliotecas com e-mail/estado

Total de bibliotecas com e-mail por estado

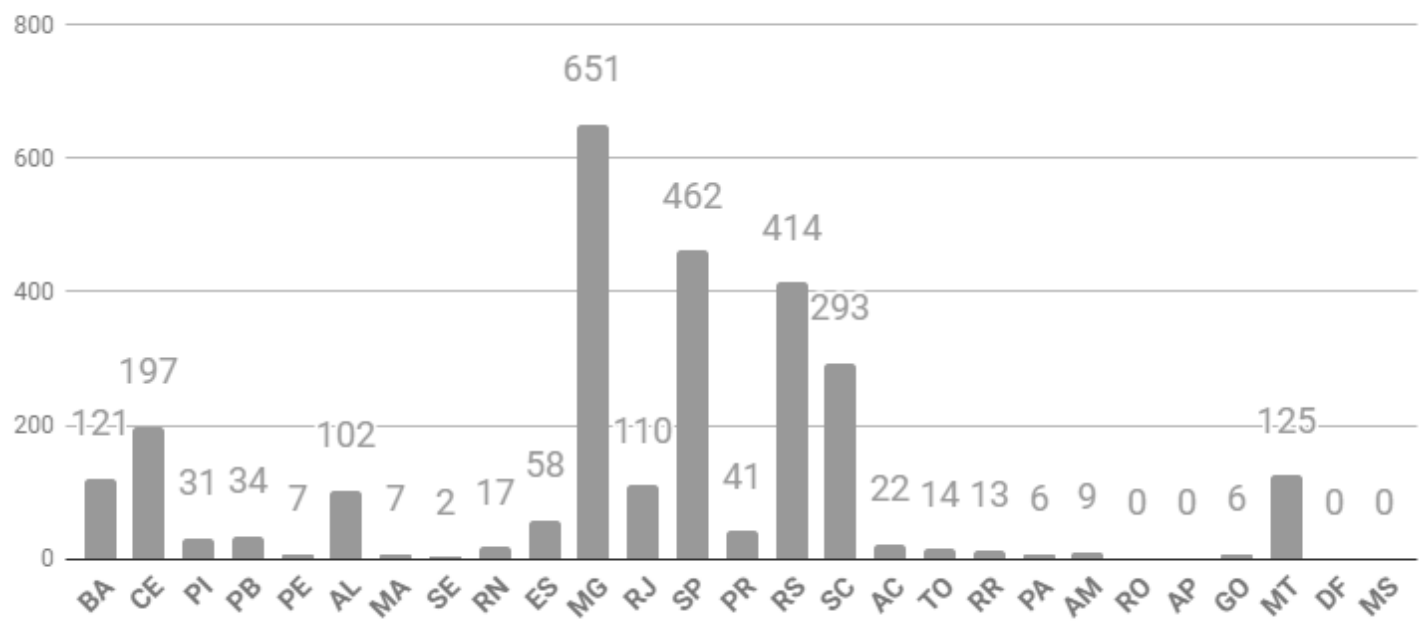

Fonte: autoria própria 
Alguns números parecem muito baixos, no entanto ao conferir o total de bibliotecas cadastradas alguns estados alcançam uma alta porcentagem de bibliotecas com endereço de e-mail, por exemplo, 0 CE tem 202 bibliotecas cadastradas no SNBP, destas, 197 têm endereços de e-mail, já SP que aparenta ter um grande número de bibliotecas com e-mail (462), quando comparado ao total de bibliotecas do estado, 842, percebe-se que esse número representa pouco mais de 50\% do total. Esses números ficam mais evidentes com o próximo gráfico.

Gráfico 6: Porcentagem de bibliotecas com e-mail/estado

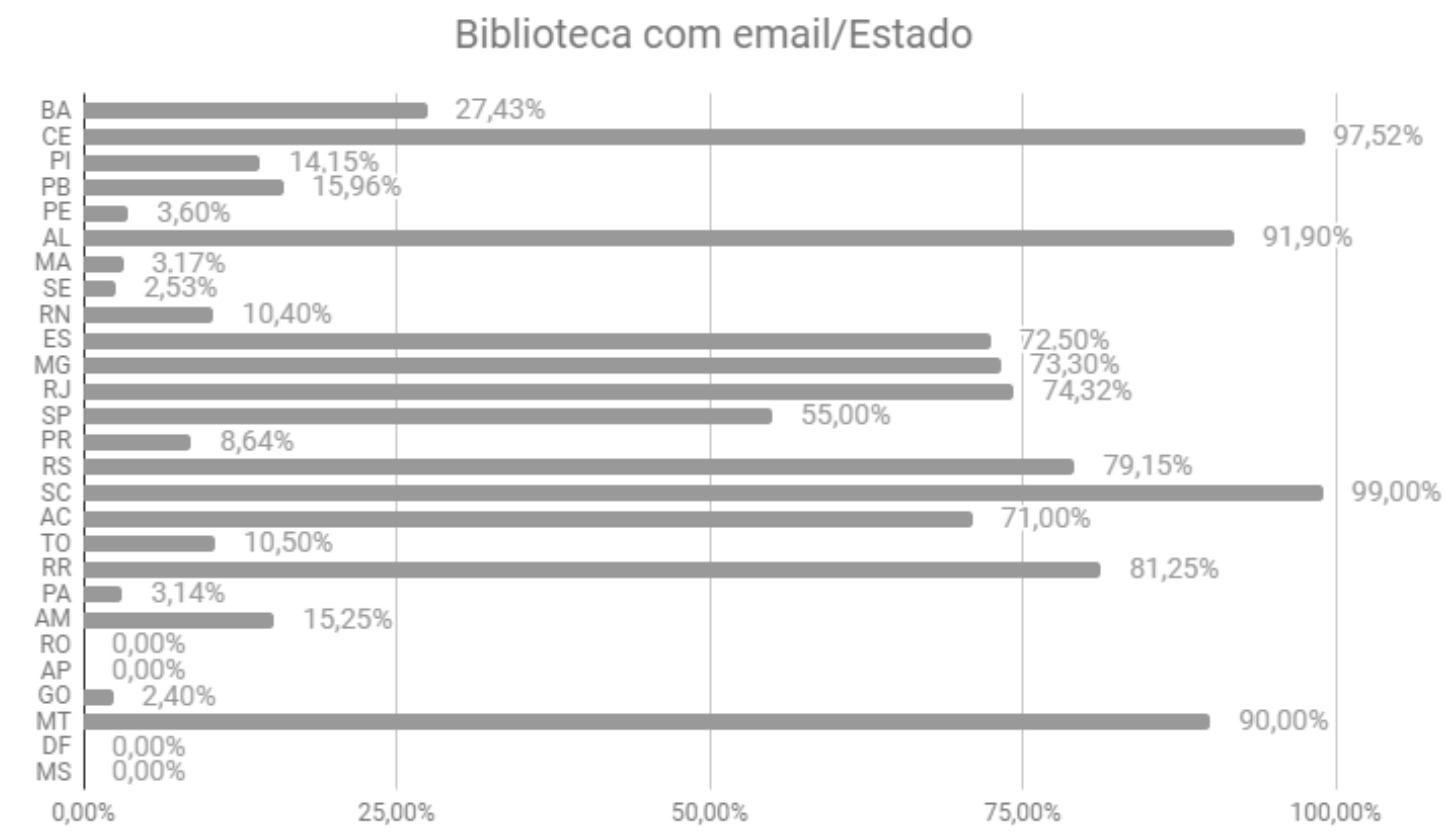

Fonte: autoria própria

Para essa análise foi considerado o total de BPs com endereço de e-mail pelo número total de BPs de cada estado. Nesse gráfico destacam-se os estados Ceará em que $97 \%$ de suas bibliotecas cadastradas no SNBP contam com endereço de e-mail. Alagoas com cerca de $92 \%$, Mato Grosso com 90\% e Santa Catarina, onde a porcentagem de BPs com endereço de e-mail chega a 99\%. No outro extremo, destacam-se os estados onde nenhuma BP apresenta endereço de e-mail, são eles: Roraima, Amapá, Mato Grosso do Sul e o Distrito Federal.

Infelizmente uma porcentagem alta de bibliotecas com e-mail não significa alto índice de resposta. A próxima Inferência é 'Índices de respostas obtidas', aqui foram analisados o total de 
respostas em relação ao total de e-mails disponibilizados, o total de respostas por estado em relação a toda amostra coletada e os efeitos dos reenvios de e-mails aliadas a busca em páginas do facebook por e-mails atualizados.

Gráfico 7: Total de respostas por estado/total de e-mail cadastrado por estado

Índice de respostas / Número de emails cadastrados

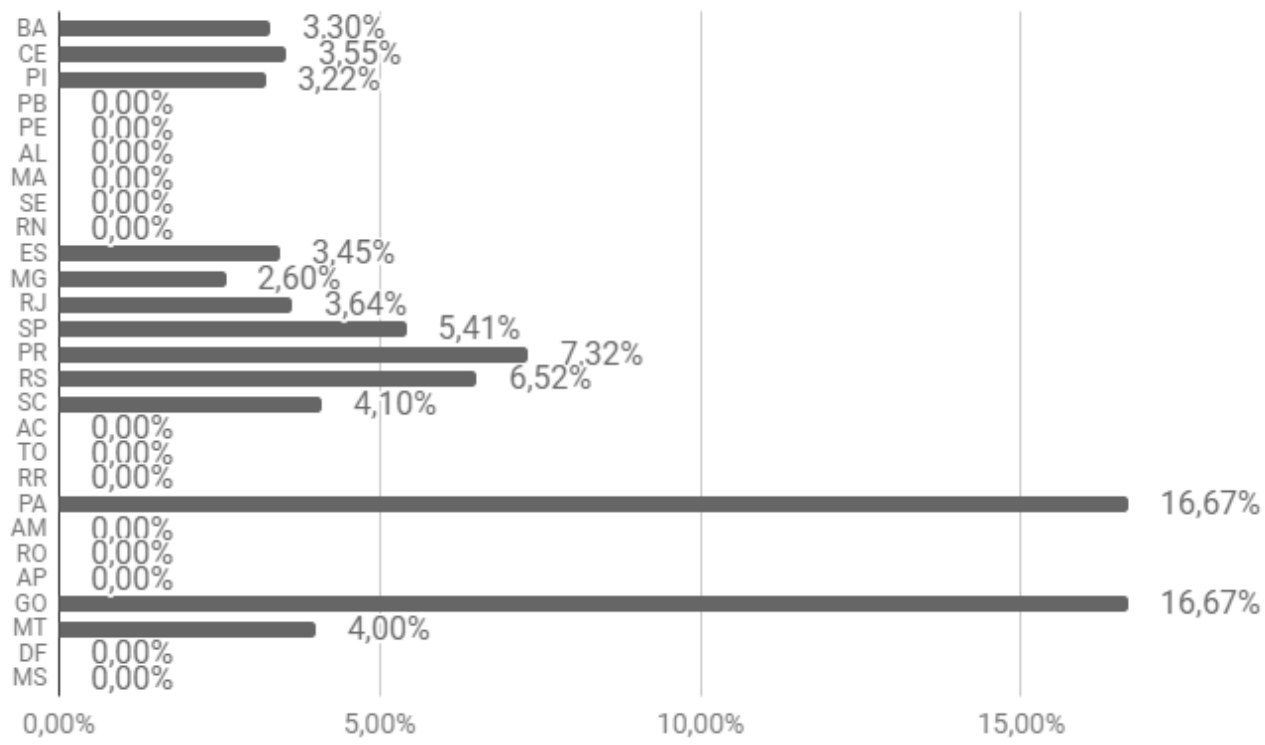

Fonte: autoria própria

Como demonstra o gráfico 6, os maiores índices de respostas, quando considerado o número de BPs cadastradas no estado, não vêm dos estados com maior número de bibliotecas. Isto significa que nos estados com maior número de e-mails cadastrados, MG (651), SP (462), RS (414), SC (293), somente responderam os e-mails, respectivamente, 2,6\%, 5,41\%, 6,52\%, 4,1\% da amostra. Destacam-se aqui os estados Pará e Goiás, ambos estavam zerados até o segundo mês do questionário ativo, após reenvio de e-mails revisados foram obtidos uma resposta de cada, o alto índice é explicaoa pelo número de BPs que possuem endereço de e-mail nesses espaços, ambos com apenas 6 BPs cada. Outro ponto a destacar é o alto número de estados que não contribuíram para a amostra, 13 e o DF no total. Os estados Roraima, Amapá, Mato Grosso do Sul e o DF não apresentaram nenhum e-mail na planilha do SNBP, com o intuito de buscar representação do máximo de estados possíveis, foram feitas buscas diretas em redes sociais, blogs e sites por e-mails das BPs desses estados, com essa ação foi possível obter respostas do Mato Grosso do Sul e do DF, como é mostrado no seguinte gráfico: 
Gráfico 8: Porcentagem de respostas em relação ao total da amostra

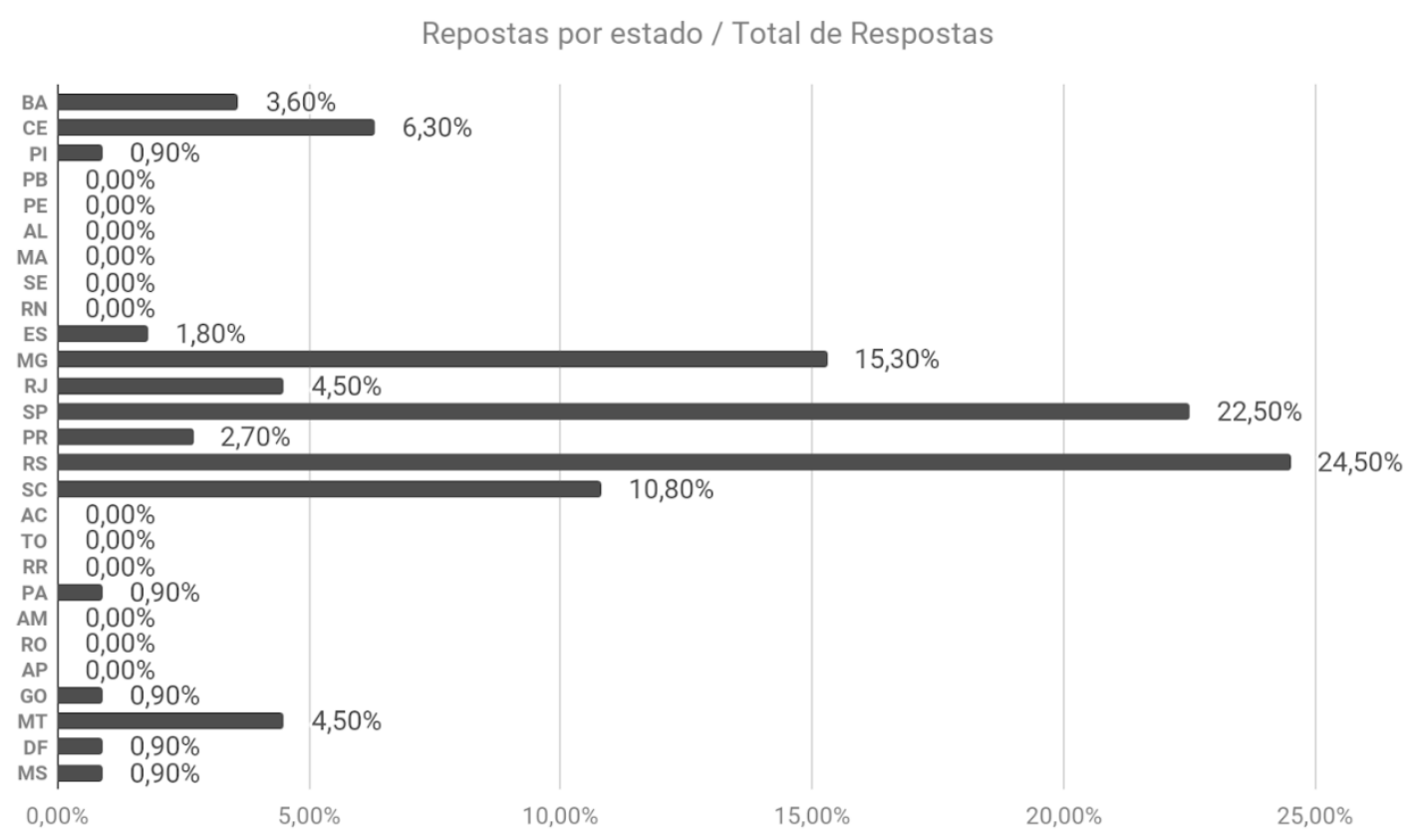

Fonte: autoria própria

0 gráfico acima considera a amostra toda, por isso MS e DF saem do 0\%. As ações de pesquisa e reenvio de e-mail não serviram apenas para reverter os estados zerados na amostra, elas também ampliaram o total de respostas em outros estados, nesse sentido destaca-se o Ceará que antes dos reenvios havia contribuído com 3 respostas, depois do reenvio o número ampliou-se para 7 . Nesse gráfico também é possível inferir que a porcentagem de respostas na amostra final é maior nos estados com maiores índices de bibliotecas com endereços de e-mails, tais como: SP, MG, SC e destaque para RS em que menos de $80 \%$ das bibliotecas possuem endereço de e-mail, índice mais baixo que o de estados como CE (97\%) e RR (81\%). Após todas as ações para ampliar o número de respostas, obteve-se uma amostra de 111 respostas válidas.

Iniciando a Categoria, 'Caracterização das Bibliotecas', tem-se a Inferência 'Tipos de Bibliotecas respondentes'. O SNBP lista oito tipos de bibliotecas cadastradas em seu sistema: Biblioteca Pública, Biblioteca Pública Temática, Biblioteca Comunitária, Biblioteca Especializada, Biblioteca/Centro de referência, Biblioteca Universitária, Biblioteca Escolar e Ponto de Leitura. 
Gráfico 9: Tipos de bibliotecas cadastradas no SNBP

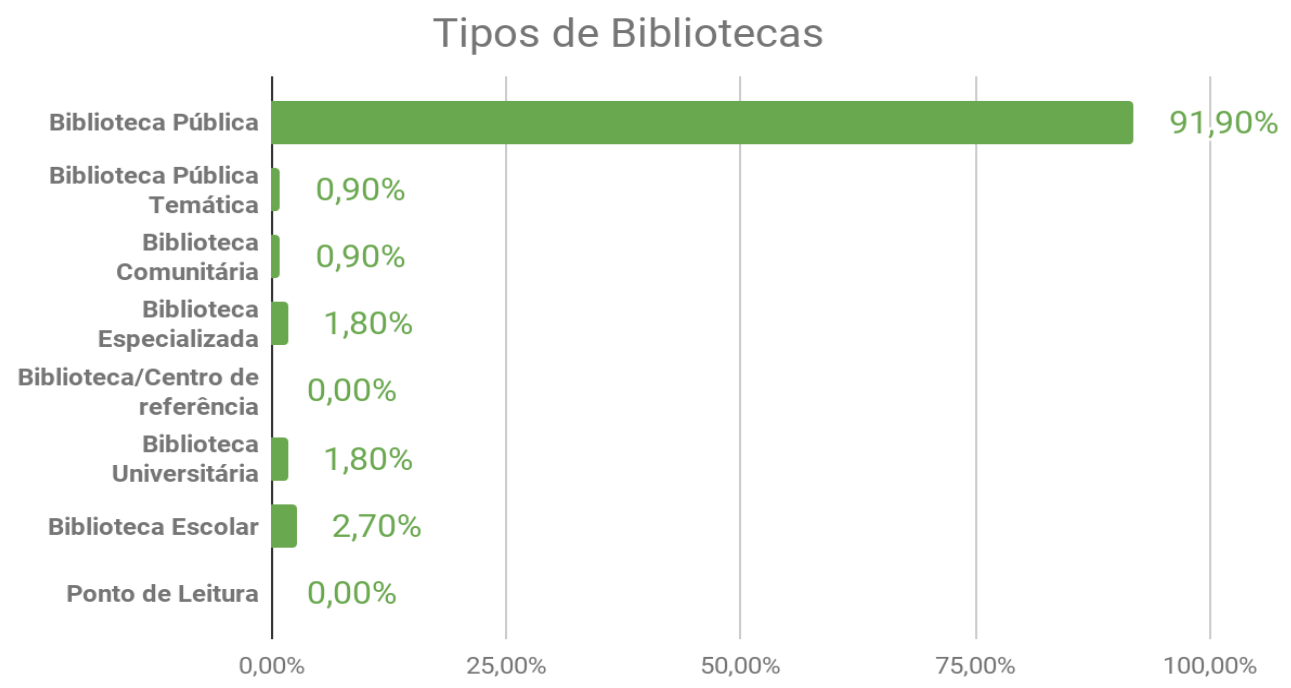

Fonte: autoria própria

Destacam-se nesse gráfico a Biblioteca Universitária e a Biblioteca Escolar que tiveram dois e três respondentes, respectivamente. As bibliotecas universitárias não estão cadastradas no SNBP, provavelmente quem respondeu os formulários são ex-funcionários de BPs que preencheram os dados no sistema informando e-mail pessoal, as planilhas mostraram que isso ocorre com frequência. Entre as bibliotecas escolares, dois respondentes indicaram que a biblioteca também atua como BP, 0 terceiro respondente atua na Secretaria de educação e cultura do município, portanto, é provável que não preencheu o questionário com as informações buscadas.

A segunda Inferência desta categoria é 'relação do horário de funcionamento das bibliotecas respondentes'. Para analisar esses dados as bibliotecas foram agrupadas em: BPs que funcionam em horário comercial, BPs que funcionam além do horário comercial, BPs que funcionam aos finais de semana e BPs que funcionam fora do horário comercial e aos finais de semana. Para esta pesquisa, considerou-se horário comercial das 8 às $18 \mathrm{hrs}$. 
Gráfico 10: Horário de funcionamento das BPs

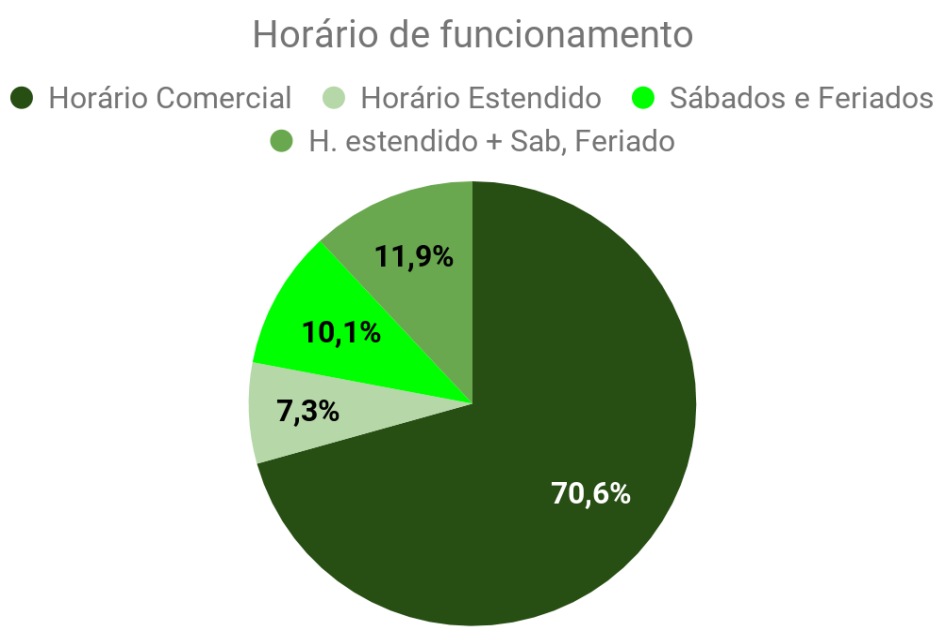

Fonte: autoria própria

Como esperado, a maioria das BPs funciona apenas em horário comercial (70,6\%). Um total de 13 BPs alegam que funcionam aos finais de semana, feriados e em horário estendido (além do horário comercial), sendo 10 em SP, 1 em MG, 1 em SC e 1 no PR, destaca-se que as únicas bibliotecas da amostra que tem expediente regularmente aos domingos são: Biblioteca "Rubem Braga" e Biblioteca “João Cabral de Melo Neto", ambas na cidade de São Paulo.

Já as bibliotecas que abrem aos finais de semana somaram 11, sendo 4 em MG, 3 no RS, 2 em SP e 2 no RJ. As bibliotecas que funcionam além do horário comercial somaram 9, sendo 5 em SC, 2 no RS, 1 em SP e 1 no RJ. Uma informação que chama atenção é o horário de funcionamento da BP Municipal "Professor Egon Andschau" da cidade de Travesseiro-RS, que tem um expediente de duas horas diárias. As demais BPs funcionam entre 0 intervalo de 6 a 12 horas por expediente.

É possível inferir que a maioria das BPs que abrem em horários alternativos está nas regiões com área metropolitana e por esse motivo, necessita de um expediente que dialogue com o ritmo de vida dos cidadãos de uma cidade mais ativa.

A grande porcentagem de BPs que funcionam apenas em horário comercial é preocupante, pois exclui boa parte da população que trabalha ou estuda em tempo integral. Essa se torna a primeira barreira no acesso à cultura de boa parte da população. Além disso, o baixo número de BPs que abrem aos finais de semana indica que haveria certa dificuldade em realizar eventos familiares na biblioteca, tais eventos visam à integração de toda a família com a comunidade a partir de atividades que despertem 
interesse em comum, a restrição do horário de funcionamento da biblioteca impossibilitaria a presença de boa parte, senão todos, os membros da família.

A Categoria ‘Caracterização do respondente’ dá seguimento a análise. Nessa categoria buscouse traçar um perfil de quem respondeu aos questionários, a maioria constitui-se de funcionários da biblioteca, apenas 10 respondentes não atuam na unidade. A primeira Inferência dessa categoria é 'Relação da Faixa Etária dos respondentes', explicitada no primeiro gráfico, mostra a porcentagem de funcionários por intervalo de idade, o intervalo com maior incidência é de 30-39 anos (35\%), seguido do intervalo $40-49$ anos (31\%).

Gráfico 11: Faixa Etária dos respondentes

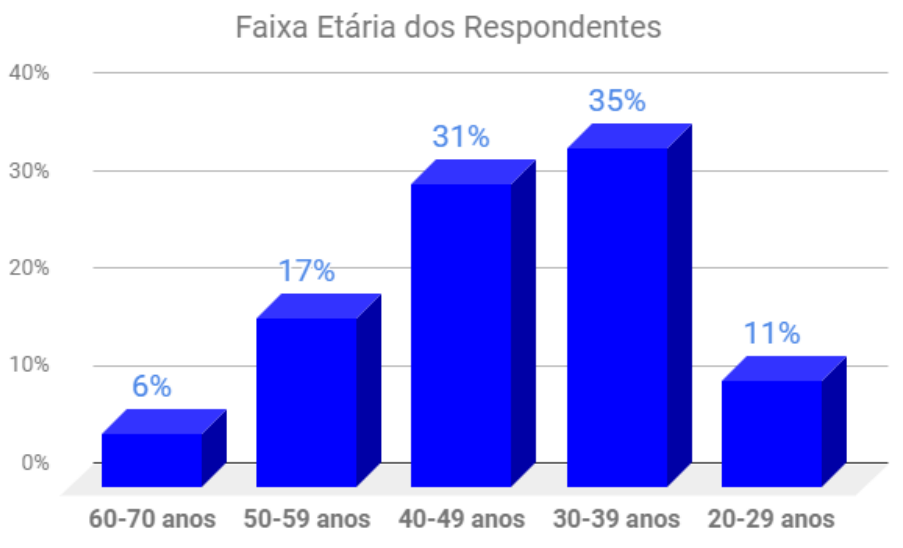

Fonte: autoria própria

A segunda Inferência é 'Gênero dos respondentes'. Quanto ao gênero do respondente, a maioria constitui-se de mulheres, somando 87 respondentes das quais 78 trabalham na biblioteca. Já os homens somam 24 respondentes, dos quais 23 são funcionários da biblioteca. Outro dado que foi possível inferir é que todos os funcionários com menos de 30 anos são mulheres.

Gráfico 12: Gênero dos respondentes

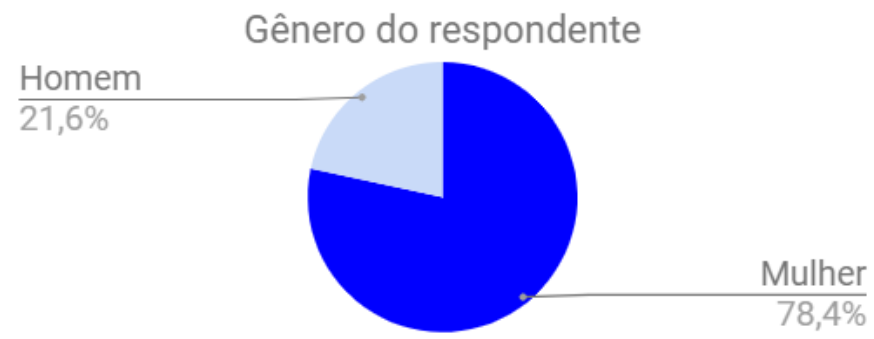

Fonte: autoria própria 
A terceira Inferência 'Tempo de atuação dos respondentes nas unidades', visa aferir há quanto tempo o respondente atua na unidade. Em relação ao tempo que o funcionário atua na BP consta um intervalo entre 20 dias e 39 anos. A maior parte dos funcionários trabalha na unidade a menos de cinco anos, indicando certa instabilidade nessa área de atuação. Confirma essa hipótese o fato de que a média de tempo de atuação na unidade, considerando o intervalo de 30-49 anos, é 7 anos, já na faixa de 50-70 anos, são 15 anos de atuação, em média. Isto significa que os profissionais mais jovens estão atuando menos tempo no mesmo local, impossibilitando o desenvolvimento contínuo de atividades na biblioteca.

Gráfico 13: Tempo de atuação na unidade

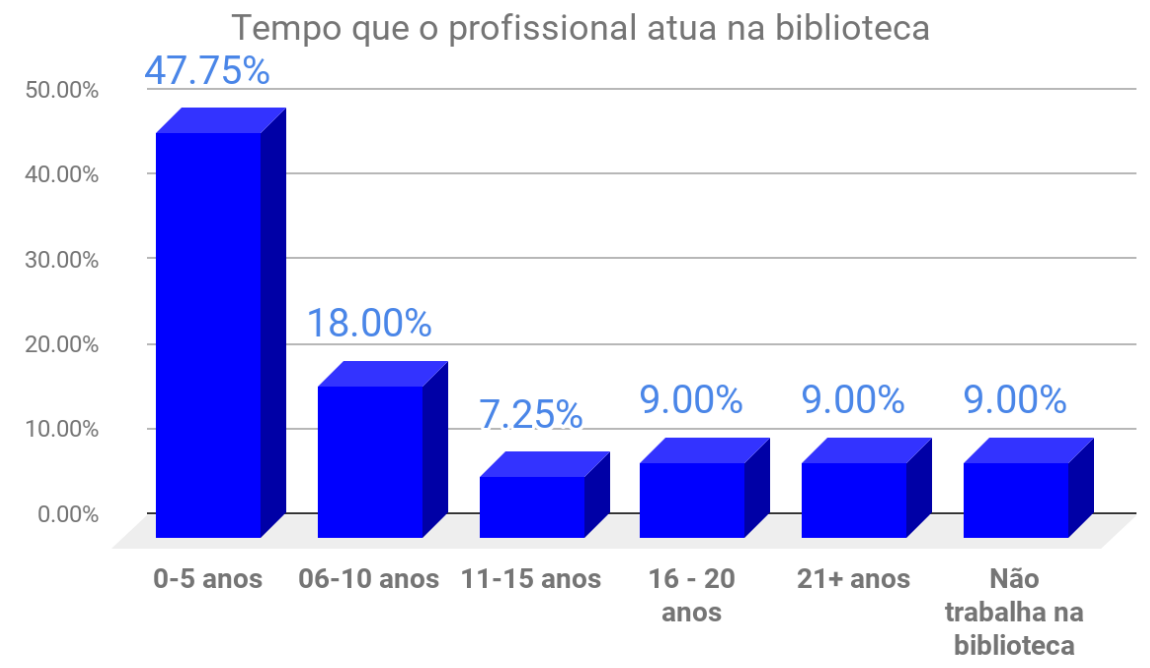

Fonte: autoria própria

\section{A Inferência 'Relação de nível e área de formação dos funcionários das bibliotecas} respondentes' está explicitada nos gráficos 14 e 15. No gráfico 14 encontra-se 0 nível de estudo dos respondentes. Os respondentes em geral têm profissão de formação (46\% nível superior) e são especializados (46\% têm especialização). 
Gráfico 14: Nível de formação do respondente

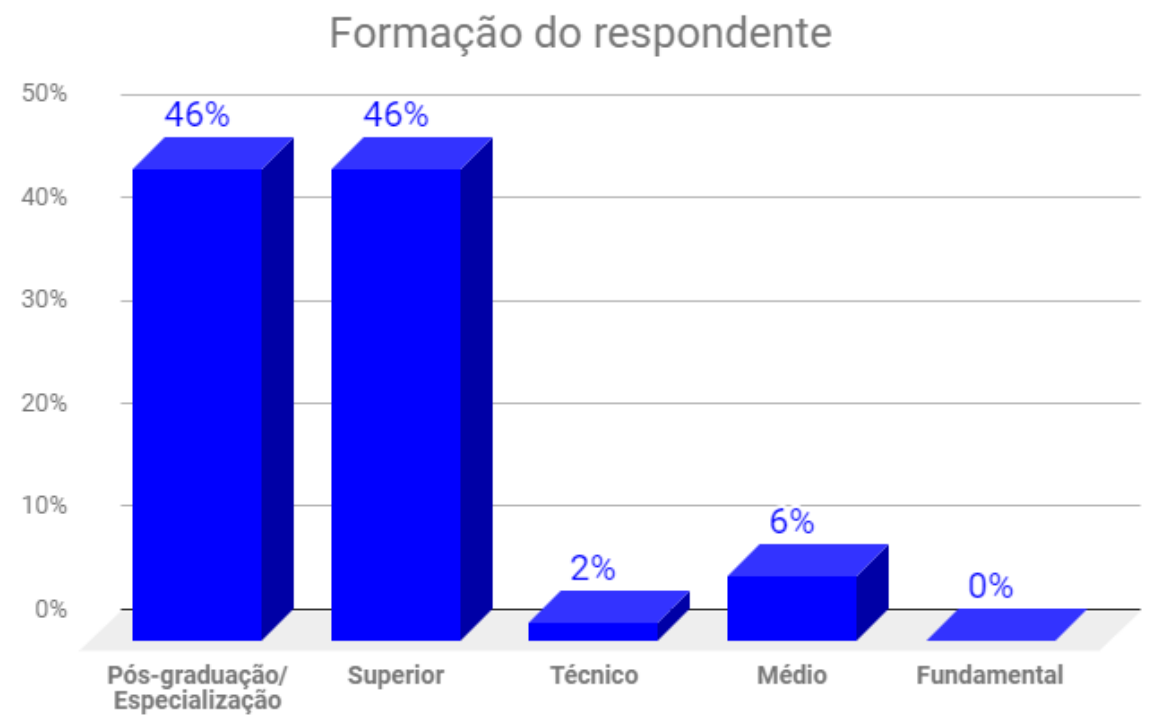

Fonte: autoria própria

Quanto à área de formação dos respondentes apenas metade da amostra é formada na área de Biblioteconomia.

Gráfico 15: Formação do respondente

Formação na área de Biblioteconomia

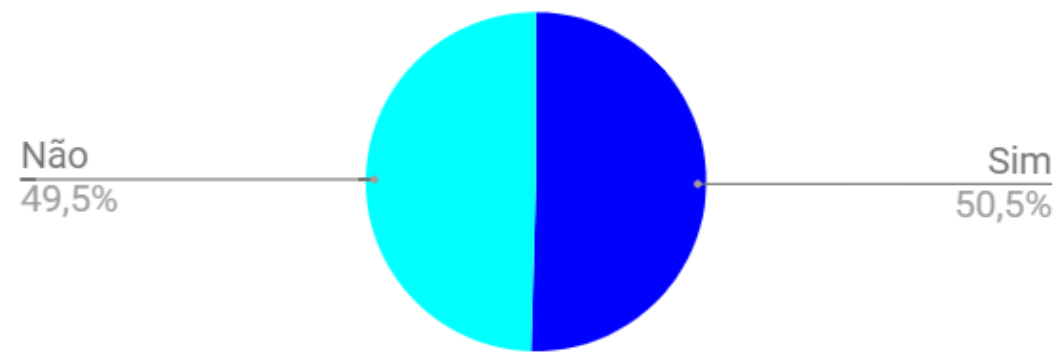

Fonte: autoria própria

Levando em conta os últimos três gráficos, são levantadas algumas hipóteses. A maioria da amostra é especializada, no entanto, metade dela não é formada na área, unindo os dois dados é possível especular que a inconsistência do tempo de atuação na unidade pode ocorrer devido a não identificação do profissional com a atividade que está exercendo, uma vez que tem outra profissão de formação. Esse dado é preocupante, pois dificilmente o profissional de outra área vai se atentar para a 
finalidade da BP, que não se limita a emprestar livros, mas também deve ser um centro de ação cultural que promova atividades que integrem a comunidade e fomente as competências dos usuários, em especial a leitura.

A Categoria 4, 'Infraestrutura e serviços das Bibliotecas', inicia-se com a Inferência 'Sobre os espaços que abrigam as Bibliotecas', nesta parte o prédio que abriga a BP foi classificado em: projetado para ser uma biblioteca, adaptado para ser uma biblioteca, se o prédio é alugado ou se está em espaço temporário.

Gráfico 16: Espaço em que a biblioteca funciona

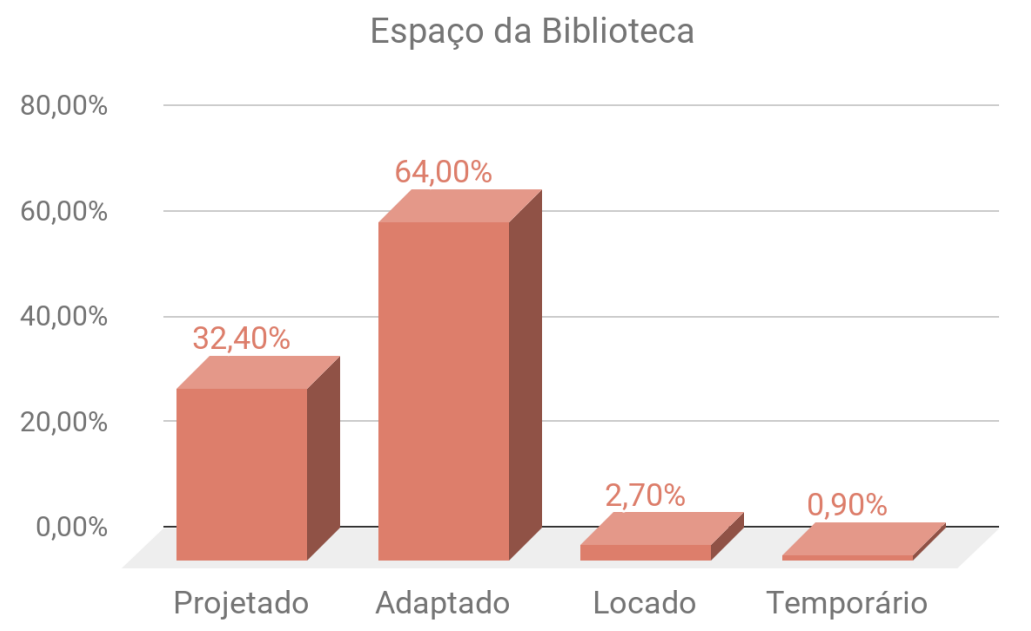

Fonte: autoria própria

Como esperado, a maioria das BPs foi adaptada em prédios já construídos (64\%), estes dados indica o desconhecimento da importância de um espaço estruturado para atender os múltiplos tipos de usuários de uma BP, tais como bebês, crianças, pessoas com deficiência, idosos, entre outros, que precisam de um espaço adequado. A negligência começa com o poder público responsável por manter a biblioteca, tais como prefeitura e secretaria de cultura, em sua maioria. Várias BPs atribuíram o e-mail da secretaria de cultura ou da educação como endereço de e-mail da biblioteca, e muitos desses e-mails retornaram por estarem incorretos ou desatualizados. Quando foi realizada a pesquisa por endereços atualizados nos sites das prefeituras, a palavra biblioteca não era mencionada entre as atribuições das secretarias na maior parte da amostra. Apenas 36 BPs (32\%) tiveram seu espaço planejado, 2 bibliotecas funcionam em espaços alugados e 1 funciona temporariamente em um centro esportivo. 
A Inferência seguinte é 'Tipos de ambientes/setores pertencentes às Bibliotecas' onde foram levantados quais ambientes constituem as BPs e se havia uma divisão de setores. No gráfico 17 são mostrados os tipos de ambientes presentes nas BPs:

Gráfico 17: Ambientes constituintes das bibliotecas

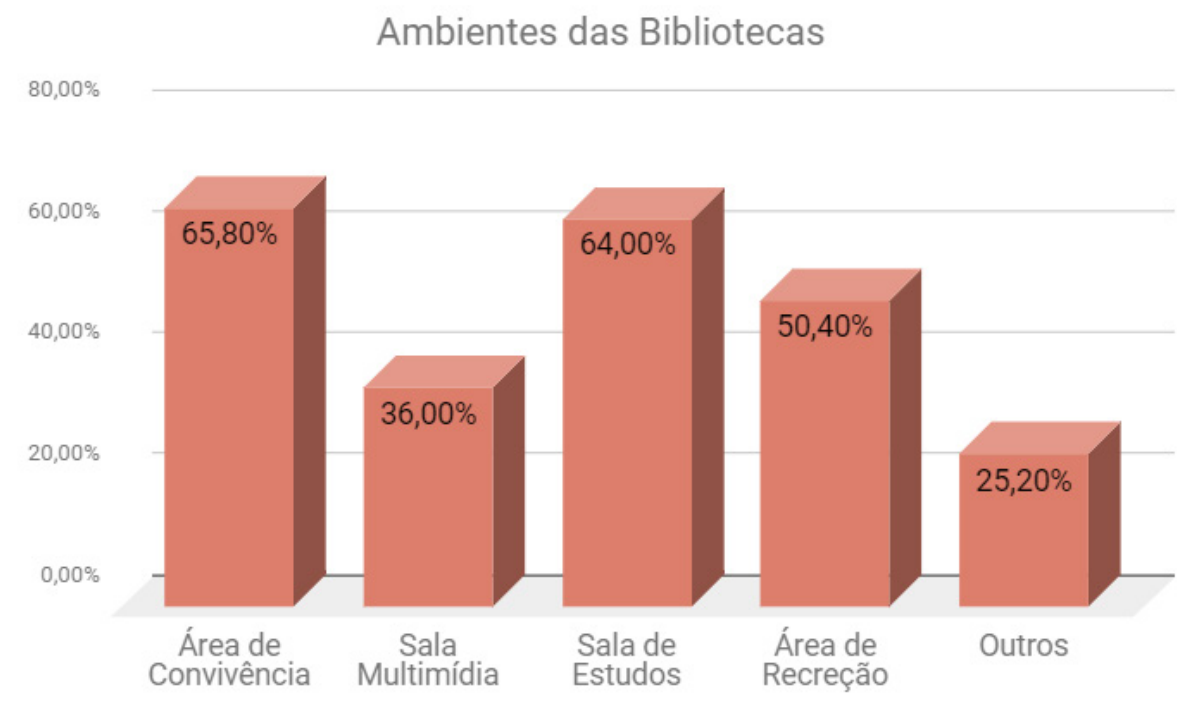

Fonte: autoria própria

Alguns respondentes afirmaram que a biblioteca é constituída de ambiente único, apenas para acomodação do acervo, confirmando a falta de conhecimento quanto à finalidade das BPs, tanto por parte do poder público, quanto por parte de quem está à frente da biblioteca. Apesar disso, 65\% das bibliotecas contam com área de convivência, 36\% possuem sala multimídia, 64\% têm salas de estudo e 50\% contam com área de recreação. Esses dados são animadores, na medida em que uma biblioteca com ambientes diversificados possuem mais condições de realizar atividades interativas e integrativas. Entre a opção "Outros” destaca-se: área infantil, cineclube, auditório, Espaço cidadão - Telecentro, sala de obras raras, sala de memórias, lan house, área de exposição, brinquedoteca, gibiteca, setor de periódicos, sala de inclusão digital, mezanino para oficinas e acervo raro, espaço de jornais e revistas, jardim e chafariz, bebeteca, DVDteca e área de reuniões.

A terceira Inferência dessa categoria é 'Recursos materiais das bibliotecas', que buscou elencar os diversos recursos que integram as instalações das BPs. 
Gráfico 18: Instalações das bibliotecas

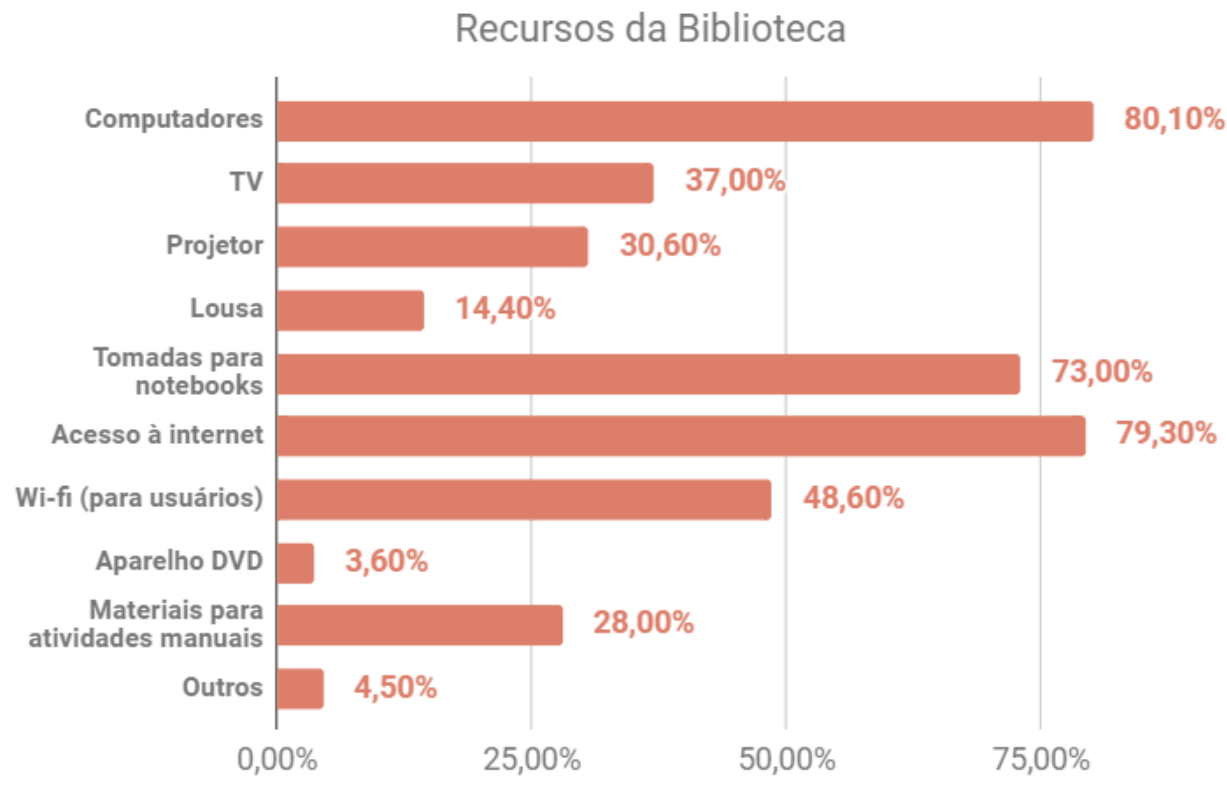

Fonte: autoria própria

Os dados mostram que boa parte das bibliotecas conta com computadores ( $80 \%)$ e acesso a internet (79\%), além disso, 73\% possuem estrutura para usuários com notebook, 37\% possuem TV e $30 \%$ projetor, todos esses recursos permitem que a unidade promova atividades que envolvam outros materiais além do livro, permitem também, o oferecimento de diversos serviços à comunidade. Na opção "Outros" destacam-se software de voz para pessoas com deficiência visual, mesas e cadeiras, bancada para notebooks, sistema de som ambiente, impressoras e equipamentos eletrônicos de Braille.

A próxima Inferência, 'Tipos de materiais pertencentes ao acervo das bibliotecas', teve 0 objetivo de listar os materiais que compunham o acervo, como é mostrado no gráfico 19: 
Gráfico 19: Materiais constituintes dos acervos

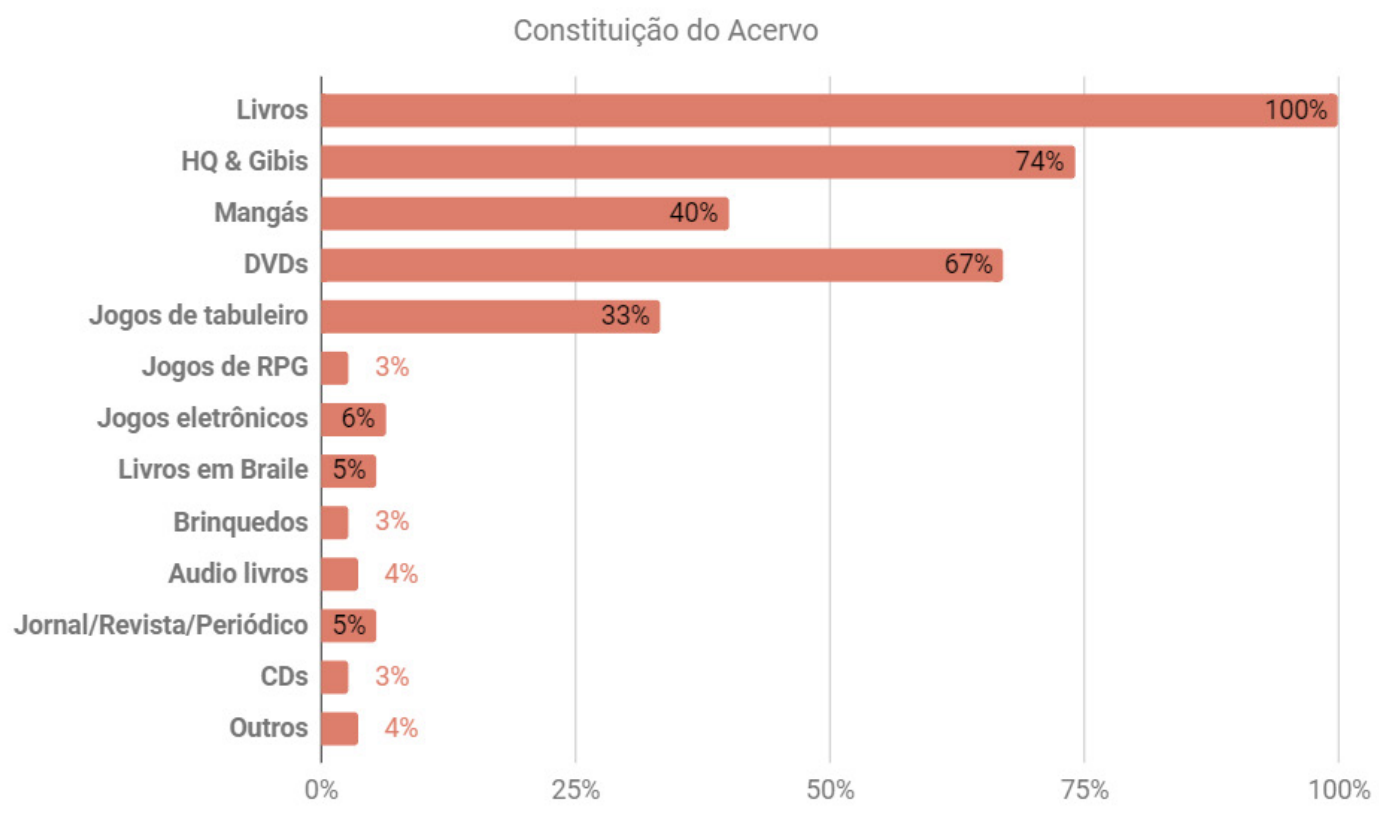

Fonte: autoria própria

Como esperado, todas as bibliotecas possuem livros em seu acervo. Outros materiais presentes em grande parte das bibliotecas são HQs e Gibis (74\%) e Mangás (40\%). Outros números a se destacar são: $67 \%$ das bibliotecas possuem DVDs, $33 \%$ possuem jogos de tabuleiro e $3 \%$ possuem jogos de RPG (jogos de interpretações de papéis), a diversidade de material apresentado é animadora na medida em que acena a possibilidade de desenvolver novas atividades, inclusive de mediação, visando à sociabilidade e integração na comunidade. Entre a opção "Outros" destacam-se: VHS e livros com letras ampliadas.

A última Inferência da categoria é 'Relação de serviços oferecidos pelas bibliotecas', na qual se pretendeu verificar quais bibliotecas desenvolvem serviços além dos básicos como empréstimo e consulta. 
Gráfico 20: Serviços oferecidos pelas BPs

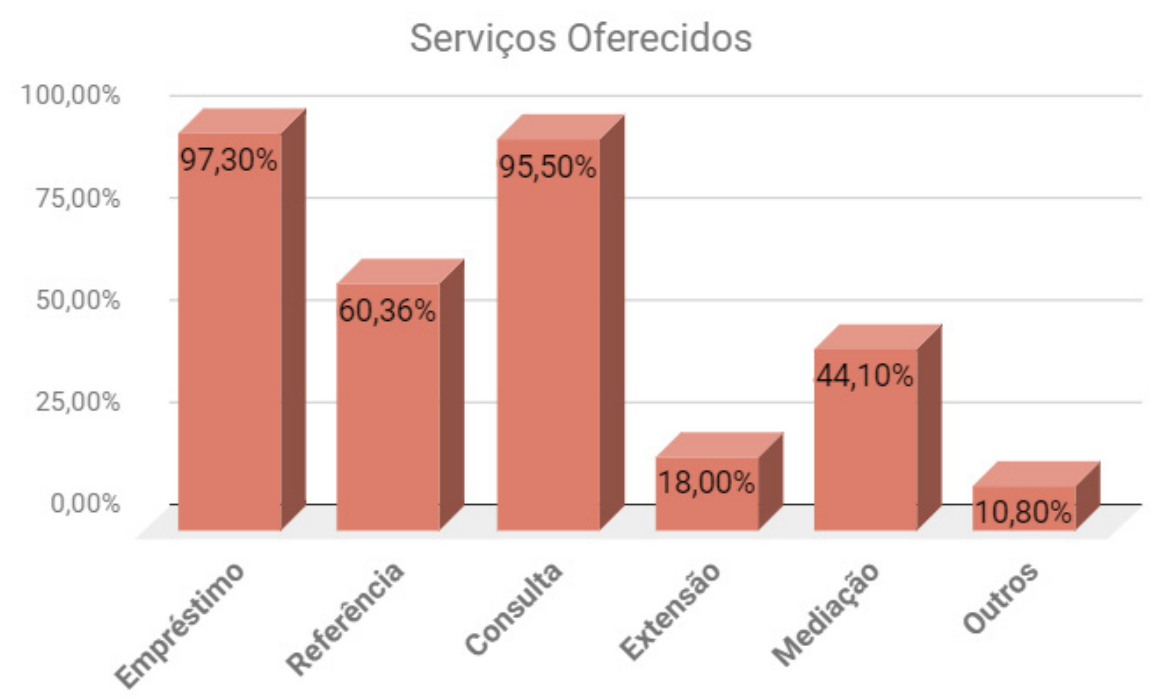

Fonte: autoria própria

Os serviços mais oferecidos são Empréstimo (97\%) e Consulta (95\%), como já era presumido. Um total de 3 instituições não oferecem serviço de empréstimo, 2 BPs e uma BP Especializada. A BP Especializada é o Centro de Documentação - "Casa da Memória” em Florianópolis, por ser um centro de documentação é compreensível que não se ofereça o serviço de empréstimo, já as outras duas BPs não apresentaram motivos evidentes para não oferecerem um serviço tão básico quanto 0 empréstimo. As duas BPs que não oferecem empréstimo são: Biblioteca Pública Municipal "Hércule Florence" - MT e Biblioteca Pública Municipal Professor "Egon Andschau” - RS, esta última já apareceu na análise como destaque acerca do expediente de apenas duas horas.

Outro serviço com bastante representação é a Referência que está presente em $60 \%$ das bibliotecas. Menos da metade das bibliotecas desenvolvem alguma atividade de mediação, esse dado é preocupante, pois a mediação é a atividade que traz à biblioteca 0 usuário que não é muito ligado a leitura, portanto, a falta desse serviço pode excluir boa parte do público em potencial. Além disso, 18\% oferecem serviços de Extensão, isto é, desenvolve serviços além do espaço físico da biblioteca, apesar da porcentagem baixa é um bom indicador, já que a Extensão representa uma forma de divulgar a biblioteca e seus serviços.

A Categoria 5, 'Recursos Humanos', teve como foco o quadro de funcionários das BPs, definindo a quantidade, a qualificação e a área de formação. A primeira Inferência é 'Número de funcionários 
que atuam nas bibliotecas', aqui fica perceptível que a maior parte das bibliotecas (30\%) operam com apenas um funcionário, seguidas de 17\% que operam com dois funcionários. Considerando apenas esses dados já é possível ter uma dimensão da dificuldade que o funcionário enfrentaria para desempenhar serviços além dos básicos de uma biblioteca.

Gráfico 21: Quantidade de funcionário por biblioteca

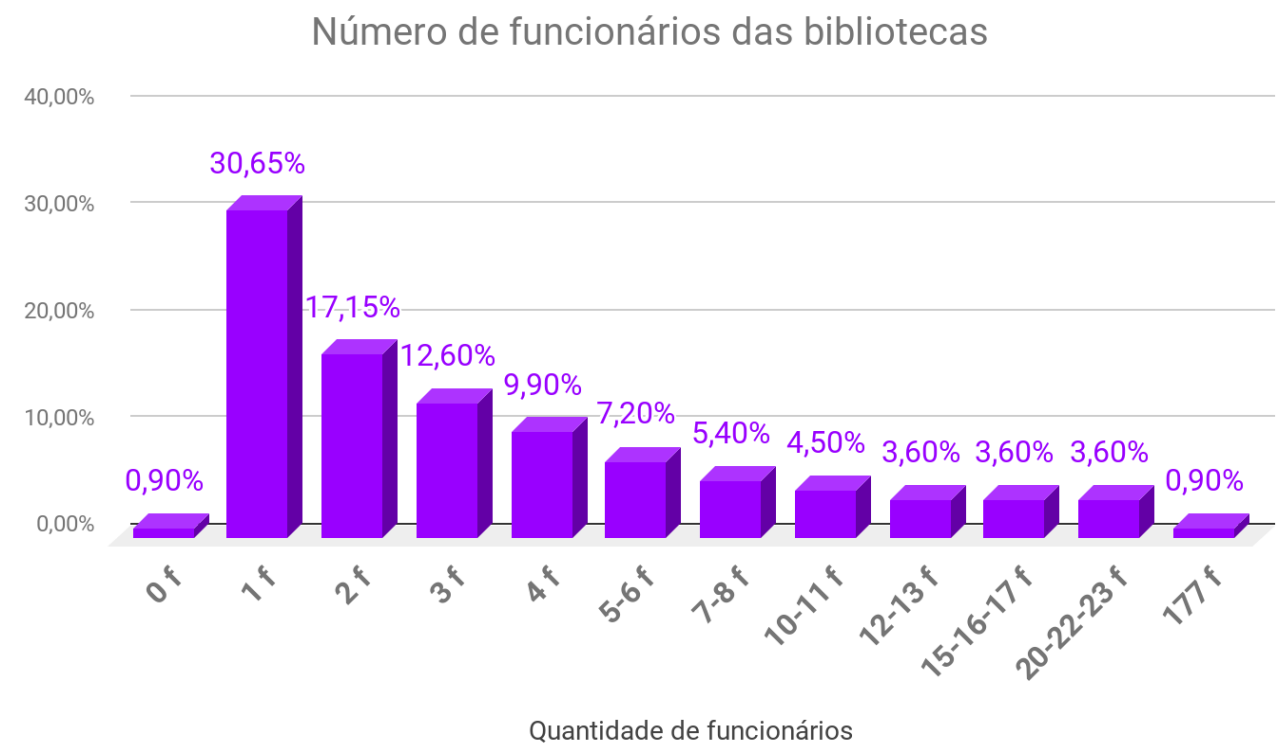

Fonte: autoria própria

Destacam-se aqui as bibliotecas com 20 funcionários ou mais, respectivamente, Biblioteca Municipal "Governador Leonel de Moura Brizola" - RJ (20), Biblioteca Pública Municipal "Prefeito Rolf Colin" - SC (20), Biblioteca Pública Estadual "Estevão de Mendonça" - MT (22), Biblioteca Pública Municipal "Prof. Nelson Foot” - SP (23) e um destaque especial a Biblioteca Pública do Paraná (estadual) que atua com um quadro de 177 funcionários. No extremo oposto está a Biblioteca Pública "Mário Quintana" em Caraá - RS que está instalada na secretaria de educação do município e não dispõe de um funcionário fixo.

A segunda Inferência nesta categoria é 'Formação do quadro de funcionários da biblioteca', que pretendeu verificar a porcentagem dos responsáveis pela Biblioteca que têm formação na área e quantos funcionários do quadro geral são formados em Biblioteconomia, como demonstrados nos gráficos 22 e 23, respectivamente: 
Gráfico 22: Área de formação do responsável pela biblioteca

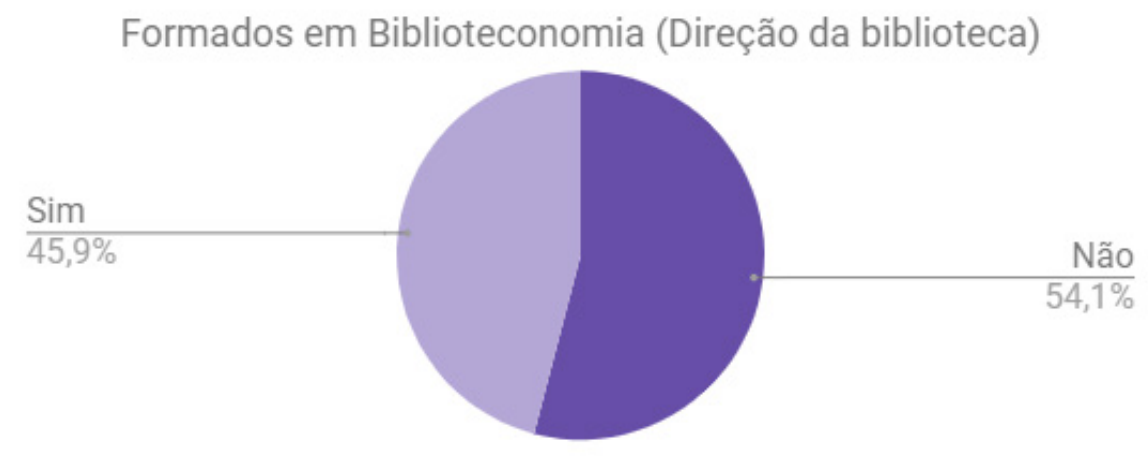

Fonte: autoria própria

Entre o quadro de responsáveis pela biblioteca, ou que atuam na direção da mesma, mais da metade não tem formação na área (54\%). Entre os que não são formados na área foram informadas as seguintes formações: Pedagogia, Administração, História e tem um respondente cursando Biblioteconomia.

No gráfico seguinte é considerado todo o quadro de funcionários da unidade para descobrir quantos dos funcionários têm formação em Biblioteconomia. Quase metade das BPs não possui nenhum funcionário formado em Biblioteconomia (44\%), seguidos de $31 \%$ que possui apenas um funcionário bibliotecário de formação.

Gráfico 23: Formação do quadro de funcionários

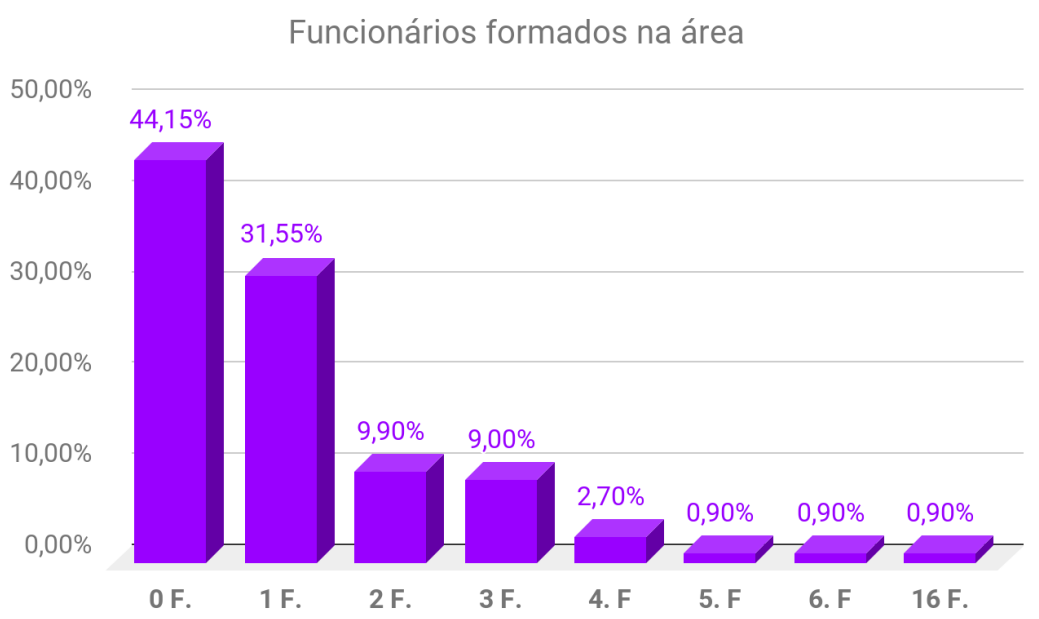

Fonte: autoria própria 
A última Inferência desta seção é Qualificação dos funcionários, nesta parte averiguou-se a existência de cursos/capacitação para atuação em bibliotecas por parte dos funcionários que não são formados em Biblioteconomia.

Gráfico 24: Funcionário com curso/treinamento na área

\section{Funcionários com cursos/treinamentos para bibliotecas}

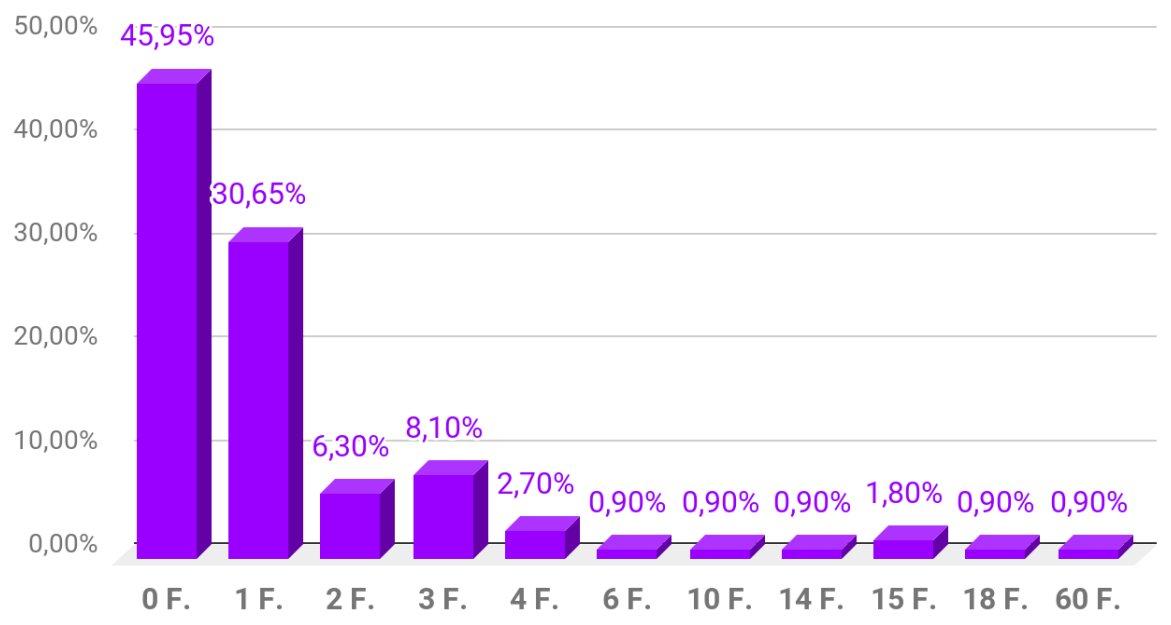

Fonte: autoria própria

Novamente, a maioria (45\%) não tem nenhuma capacitação para atuar em bibliotecas, 0 dado é ainda mais preocupante quando considerado que as BPs têm um caráter social mais evidente. Em 30\% das BPs há um funcionário capacitado para atuar nesses espaços. Os números dos dois últimos gráficos são inquietantes, pois a esmagadora maioria das pessoas que atuam em BPs não tem nenhuma capacitação para tal. Isto não significa que qualquer bibliotecário faria um trabalho melhor ou que os funcionários atuais das bibliotecas são incompetentes, o problema vai muito além. Por serem órgãos públicos entende-se que a maioria, senão todos, que atuam nesses espaços são concursados, a questão que fica é: porque as prefeituras não abrem editais para contratar o profissional bibliotecário? Será por falta de desconhecimento? Ou será porque instalam as bibliotecas em outros prédios públicos e remanejam algum funcionário já concursado que atue em outro setor?

Seja como for, a situação é inquietante, pois demonstra no mínimo desconhecimento da importância dessa instituição para a comunidade, já que em muitos locais a BP é a única instituição de cultura do município e no máximo, demonstra descaso, descaso com a instituição, com os profissionais bibliotecários e, principalmente, com a comunidade. 


\section{CONSIDERAÇÕES FINAIS}

A análise apresentou dados, por vezes, desoladores e muito preocupantes. É certo que essas instituições têm sido negligenciadas há tempos nas diferentes hierarquias administrativas em que estão inseridas. Falta investimento, conscientização e representação por parte dos órgãos de classe.

Os obstáculos da pesquisa começaram na coleta dos endereços de e-mail, pois muitos estavam desatualizados, incorretos ou fora de contexto. Ao SNBP caberia estabelecer uma política de cadastramentos das bibliotecas, uma vez que cada unidade preenche seus dados, deveria haver algum material para guiá-las no cadastramento. Outros obstáculos envolveram a baixa adesão ao questionário, 0 descomprometimento de uma minoria de respondentes que abandonaram o preenchimento no meio do formulário. Ainda assim, o comprometimento da maioria, garantiu que a pequena amostra proporcionasse uma boa contextualização da realidade dessas instituições, demonstrando elementos tangíveis e corpóreos acerca das bibliotecas públicas brasileiras e elevando a reflexão entre 0 ideal e 0 real.

As BPs devem agir de forma a garantir que essas instituições contem com um profissional formado na área, adequem o horário de funcionamento e 0 número de funcionários de acordo com as necessidades da comunidade, invistam em novas iniciativas a partir do estudo de usuário, articulem parcerias com artistas e profissionais locais para realização de oficinas e cursos de interesse da comunidade, busquem doações de materiais e cumpram, na medida do possível, o papel de transformação social da Biblioteca Pública.

\section{REFERÊNCIAS}

AMAD0, João. Manual de investigação qualitativa em educação. Coimbra: Imprensa da Universidade de Coimbra, 2013.

BARDIN, Laurence. Análise de Conteúdo. São Paulo: Edições 70, 2011.

CALIXTO, José António. Literacia da informação: um desafio para as bibliotecas. Homenagem ao Professor Doutor José Marques, Faculdade de Letras da Universidade do Porto. 2003. Disponível em:

http://ler.letras.up.pt/uploads/ficheiros/artigo5551.PDF. Acesso em: 10 abr. 2018.

CHIZZOTTI, Antônio. Pesquisa em ciências humanas e sociais. 12. ed. São Paulo: Cortez, 2018. 
FUNDAÇÃO BIBLIOTECA NACIONAL. Biblioteca Pública: princípios e diretrizes. 2. ed. Rio de Janeiro: Fundação Biblioteca Nacional, 2010.

GIL, Antonio Carlos. Como elaborar projetos de pesquisa. 4. ed. São Paulo: Atlas, 2002.

GILL, Philip (Org.). Os serviços da biblioteca pública: directrizes da IFLA/UNESCO (2001). Lisboa: Editorial Caminho e Associação Liberpólis, 2001.

IBGE. Estimativas da população residente no brasil e unidades da federação com data de referência em $1^{0}$ de julho de 2016. 2016. Disponível em: ftp.ibge.gov.br/Estimativas_de_Populacao/ Estimativas_2016/estimativa_TCU_2016_20170614.pdf. Acesso em: 10 nov. 2018.

INSTITUTO PRÓ-LIVRO. Retratos da Leitura no Brasil. 4. ed. 2016. 142 slides. Disponível em: http:// prolivro.org.br/home/images/2016/Pesquisa_Retratos_da_Leitura_no_Brasil_-_2015.pdf. Acesso em: 20 mar. 2018.

INSTITUTO REUTERS. Relatório de Notícias Digitais. 2018. Disponível em: http://www. digitalnewsreport.org/survey/2018/brazil-2018/\#fn-8099-2. Acesso em: 07 Out. 2018.

MANIFESTO IFLA/UNESCO sobre bibliotecas públicas. 1994. Disponível em: https://www.ifla.org/files/ assets/public-libraries/publications/PL-manifesto/pl-manifesto-pt.pdf. Acesso em: 10 abr. 2018.

MEY, Eliane Serrão Alves. Bibliotheca Alexandrina. Revista Digital de Biblioteconomia e Ciência da Informação, v. 1, n. 2, 2004. Disponível em: https://periodicos.sbu.unicamp.br/ojs/index.php/rdbci/ article/view/2081/2211. Acesso em: 03 Out. 2018.

MILANESI, Luis. Biblioteca. São Paulo: Ateliê Editorial, 2002.

MILANESI, Luís. Biblioteca pública: do século XIX para o XXI. São Paulo, Revista USP, n. 97, p. 5970, 2013. Disponível em: http://www.periodicos.usp.br/revusp/article/viewFile/61685/64574. Acesso em: 10 abr. 2018.

OECD (2000). Literacy in the information age: final report of the international adult literacy survey. Paris: OECD, 2000. Disponível em: http://www.oecd.org/education/skills-beyond-school/41529765. pdf. Acesso em: 10 abr. 2018.

SISTEMA NACIONAL DE BIBLIOTECAS PÚBLICAS (SNBP). Sobre. 2018. Disponível em: http://snbp. cultura.gov.br/sobre/. Acesso em: 05 de nov. 2018.

SUAIDEN, Emir José. A biblioteca pública no contexto da sociedade da informação. Ciência da Informação, Brasília, v. 29, n. 2, p. 52-60, maio/ago. 2000. Disponível em: http://www.scielo.br/pdf/ ci/v29n2/a07v29n2.pdf. Acesso em: 18 jan. 2018.

SUAIDEN, Emir José. Biblioteca pública e informação à comunidade. São Paulo: Global, 1995. 